\title{
Improving Concept Understanding Ability Using Think Talk Write Learning Model in Mathematics Lessons at SD Negeri 42 Banda Aceh
}

\author{
Indah Suryawati ${ }^{*}$, Khairul Asri ${ }^{2}$ \\ ${ }^{1}$ Department of Primary School Teacher Education, Faculty of Teacher Training and \\ Education, Universitas Serambi Mekkah, Aceh, Indonesia \\ ${ }^{2}$ Department of Mathematics Education, Faculty of Teacher Training and Education, \\ Universitas Serambi Mekkah, Aceh, Indonesia \\ *Corresponding Author: Indah.suryawati@serambimekkah.ac.id
}

\begin{abstract}
Elementary school is the main foundation in developing an understanding of mathematical concepts. If the basic understanding of students' concepts is not good or weak, then students can't solve math problems. Therefore, understanding the concept is important to help students in learning mathematics. In the learning process the teacher doesn't optimize the methods, strategies or learning models. So far, the learning process is only focus by explanations or examples of questions, as a result, when students are faced with different questions, students have difficulty solving problems. This happens because the lack of students' conceptual understanding skills. The purpose of this study was to determine the increase in the ability to understand mathematical concepts through the Think Talk Write learning model. This study uses a quantitative approach, while the design used in this study is the Pre Experiment One group pretest and posttest design. The populations in the study were all students at SD Negeri 42 Banda Aceh, totaling 50 students. The sample in this study was the $V A_{1}$ grade students as the experimental class, while the $V A_{2}$ grade as the control class. Based on the analysis of research data, it is stated that the value of sig. (2-tailed) the N-Gain score is 0.000 less than 0.05 so Ho is rejected and Ha is accepted.
\end{abstract}

Keywords: Concept Understanding Ability; Mathematics Lesson; TTW.

\section{Introduction}

The branch of science that uses logic and is universal in nature can play a role in the development of modern technology known as mathematics. Mathematics lesson includes several things, namely: the ownership of values and attitudes, understanding concepts, and the ability to apply them in life Suyanto. Currently the application of mathematics has been applied in all levels of education in order to solve a problem logically, analytically, critically, and creatively. One of the mathematical abilities needed in learning mathematics based on purpose understands the concept (Novitasari, 2016). In fact, currently many students in mathematics lesson do not understand the concepts being studied, students often make mistakes due to miscalculations or students' thinking ability in responding to mathematical language is very less. This is because some of the teacher's learning processes have not optimized the use of learning media, have not advertise to understand of mathematical concepts strongly, and deficient of active participant students in learning process (Achmad et al., 2018).

The 2006 curriculum, states that mathematics is intended to enable students to understand concepts, use reasoning, solve problems, and communicate ideas. In this case, the based learning is how to understand basic mathematical concepts (Sri and Asih, 2017). The ability to understand concepts can be seen when a student is able to (1) re-explain what has been learned (2) use mathematical concepts with different problems (3) develop a concept from existing concepts. With this, students can be said have a good understanding the 
concept. Therefore, understand mathematical concepts can be the basis for the ability in learning mathematics that must be had by every student (Putri et al.,, 2020).

The Think Talk Write (TTW) learning model can be an option for cooperative learning, where this learning model can hone and develop students' critical thinking skills and communicated actively in discussion forums, and then students rewrite the results of these thoughts (Indrayani et al.,, 2018). The activity of "think" can be found in the process of reading a mathematical text which is then made important notes from the text. Next, the process of "talk" which is interpreted as communication and discussion between friends in a language they understand. This "talk" stage can hone students' abilities to be skilled at speaking and expressing opinions. The final stage of this method is "write" which aims to write solution to the problem and calculations according to the questions given (Agusi et al.,, 2017).

The use of the Think Talk Write method also involves students to dialogue independently after going through the process of reading, discussing and sharing ideas with other students, then writing down the results of the discussion. The method in this TTW model can be effectively applied in heterogeneous groups consisting of 3-5 students (Kurniawati et al., 2018). The steps of the learning process through the TTW learning model based on pictures are the teacher explaining in outline the material to be studied through the TTW learning model, then students are distributed student for solve a problem related to the mathematical material described by the teacher, then students start learning with the TTW learning model. Students begin to understand the concept of learning and make notes of the results of their understanding individually, to be brought to a discussion forum, and then students interact and collaborate with friends to discuss alternative answers. The teacher acts as a mediator of the learning environment, and the last step, students construct their own knowledge as a result of collaboration. After everything is finished the teacher asks students individually to explain in front of their friends (Suryawatii et al., 2019).

Based on the above study, this study aims to determine the increase in the ability to understand concepts before and after being taught using the Think Talk Write learning model.

\section{Method}

This study uses a quantitative approach, while the design used in this study is a Quasi Experiment Pretest-Posttest Control Group Design. The data needed in this study were collected by providing math problems related to understand concepts in expressing mathematical ideas using the Think Talk Write (TTW) learning model. While the test instrument was used to measure the ability to understands the concept in this study in form of math problems. Before being given treatment, the researcher first gave the students an initial test by giving math test questions related to understanding the concept. And then researchers provided the treatment by providing knowledge about the ability to understand concepts,

The populations in the study were all students at SD Negeri 42 Banda Aceh, totaling 50 students. The sample selection in this study used a purposive sampling technique because mathematics has been specifically applied to high grades, namely grades IV, V and VI. From the three classes, the researcher chose class V students as samples in this study, considered capable of Standards compared to grades IV and VI. The sample in this study was the

grade students as the experimental class, while the grade as the control class.

The data analysis in this study aims to see an increase in the ability to understand concepts using the N-Gain formula by determining in advance (1) the Normality Test is used to determine whether the data is normal using the Kolmogrov Smirnov statistical test, (2) Homogeneity Test to determine whether the group Experimental and Control have the same variance. The test used is the Levene's Test statistical test, and (3) The average difference 
test, if the two groups are normally distributed and homogeneous, then the statistical test used is the t-test using SPSS for windows standard version 17.0, namely the Independent-Simple T-Test

\section{Results and Discussions}

\section{Pretest Data Analysis of Concept Understanding Ability.}

In accordance with the purpose of conducted pretest, namely to find out the similarity of students' initial abilities to the ability to understand concepts in geometry material, the data from the pretest tested to see the similarity of the two averages. The following is a descriptive statistical analysis of the experimental and control class pretest data.

Table 1. Descriptive Statistics of Pretest Data Ability to Understand Concepts in

\begin{tabular}{lcccccc}
\hline \multicolumn{1}{c}{ Class } & N & Minimum & Maximum & mean & Variance & Std. Deviation \\
\hline Experiment & 15 & 42.00 & 64.00 & 53.73 & 32,210 & 5,68 \\
\hline Control & 14 & 45.00 & 60.00 & 52.36 & 18,401 & 4,29 \\
\hline \multicolumn{7}{c}{ Experiment Class and Control Class }
\end{tabular}

Based on Table 1, it can be seen that the average pretest scores of the experimental class and control class are 53.73 and 52.36 with a standard deviation of 5.68 for the experimental class and 4.29 for the control class. These results indicate that there is a difference between the students' average pretest in the experimental class and the control class. However, to find out whether the difference is significant or not, a statistical analysis test is carried out which includes: normality test, homogeneity test and average difference test.

a. Normality Test Pretest Ability Ability Concept Understanding

The results of the normality analysis of the Kolmogorov-Smirnov test for the pretest data for the experimental class and the control class are presented in Table 2 below.

Table 2. Normality Test Results of Pretest Data for Concept Understanding Ability

\begin{tabular}{lcccc}
\hline \multirow{2}{*}{ Class } & \multicolumn{3}{c}{ Kolmogorov-Smirnova } & \multirow{2}{*}{ Conclusion } \\
\cline { 2 - 4 } Experiment & Statistics & df & Sig. & \\
\hline Control & 0.167 & 15 & 0.200 & $\mathrm{H}_{0}$ accepted \\
\hline
\end{tabular}

Based on Table 2 above, it can be seen that the pretest score of the concept understanding ability of the experimental class has a value of Sig. more than $\alpha=0.05$ which is 0.200 and the control class has a value of Sig. more than $\alpha=0.05$ which is 0.200 . This shows that the pretest data of the experimental class and the control class are normally distributed and will be continued with the homogeneity test.

b. Homogeneity Test Pretest Concept Understanding Ability

Table 3. Results of Homogeneity of Pretest Data on Concept Understanding Ability

\begin{tabular}{lcccc}
\hline Class & Levene & Sig. & Conclusion & Information \\
\hline Experiment & 0.406 & 0.529 & accept $H_{0}$ & Homogeneous \\
\hline Control & & & & \\
\hline
\end{tabular}


Based on Table 3 above, it can be seen that the pretest score of the concept understanding ability of the experimental class and control class has a value of Sig. more than $\alpha=0.05$ which is 0.529 . This shows that the pretest data for the experimental class and the control class are homogeneous. Next, it will be continued with the test of the difference in the average $\mathrm{N}$-gain ability to understand concepts in the experimental class and control class which is carried out to answer the hypothesis.

c. Test of mean difference Pretest of concept understanding ability

Table 4. Results of the Difference in Average Pretest of Concept Understanding Ability

\begin{tabular}{lcccc}
\hline & Class & t-count & Sig. (2-tailed) & Conclusion \\
\hline Experiment & 0.732 & 0.470 & Reject $\mathrm{H}_{0}$ \\
\hline Control & & 0.732 & \\
\hline
\end{tabular}

Based on Table 4 above, it can be seen that with a significance level of $\alpha=0.05$, the Sig value is obtained. (2-tailed) is 0.470 so that Ho is accepted, and $\mathrm{Ha}$ is rejected. Thus, it can be concluded that there is no difference in the average pretest between the experimental class and the control class taught using the Think Talk Write learning model. This means that the initial ability to understand the concepts of the experimental class and control class students is the same.

\section{d. Posttest Data Analysis Concept Understanding Ability}

Post-test was carried out after learning by applying the Think Talk Write model to the experimental class and learning by applying conventional learning to the control class. Posttest is carried out when learning has ended or at the last meeting. The following is a descriptive analysis of the experimental and control class post-test data.

Table 5. Descriptive Statistical Results of Posttest Data Ability to Understand Concepts in Experiment Class and Control Class

\begin{tabular}{lcccccc}
\hline \multicolumn{1}{c}{ Class } & N & Minimum & Maximum & mean & Variance & Std. Deviation \\
\hline Experiment & 15 & 76.00 & 97.00 & 90.33 & 40.95 & 6.39 \\
\hline Control & 14 & 68.00 & 82.00 & 75.71 & 17.45 & 4.18 \\
\hline
\end{tabular}

Based on Table 5 shows that the average post-test ability of the experimental class is 90.33 and 75.71 in the control class. The average post-test of the two classes has increased compared to the average pre-test of the ability to understand concepts before.

\section{Analysis of Concept Understanding Ability Improvement}

Furthermore, to find out whether the increase in the ability to understand the concept of the experimental class and the control class is significantly different, it is necessary to test the analysis of the average difference on the N-Gain data from the two classes. In accordance with the purpose of the $\mathrm{N}$-gain calculation, namely to determine the increase in the ability to understand concepts after learning by applying the Think Talk Write model for the experimental class and learning with the application of conventional learning in the control class, the $\mathrm{N}$-gain data was tested to find out a better improvement between the two classes that were sampled in this study. Descriptive statistics on the $\mathrm{N}$-gain value of the experimental class and the control class can be seen in the following table. 
Table 6. Descriptive Statistics of N-gain Data Concept Understanding Ability

\begin{tabular}{lcccc}
\multicolumn{1}{c}{ Class } & N & mean & Variance & Std. Deviation \\
\hline Experiment & 15 & 0.796 & 0.014 & 0.118 \\
\hline Control & 14 & 0.476 & 0.015 & 0.124 \\
\hline
\end{tabular}

Based on table 6 above, it can be seen that the average $\mathrm{N}$-gain in the control class and the experimental class is 0.79 and 0.47 . The data shows that the average increase in the ability to understand concepts of the experimental class students is better than the control class. However, further statistical tests are needed to determine that the improvement in the experimental class is better than the control class by means of a two-mean difference test or a t-test.

a. N-Gain Normality Test Ability Concept Understanding Ability

Table 7. Results of the N-Gain Data Normality Test for Concept Understanding Ability

\begin{tabular}{lcccc}
\hline \multirow{2}{*}{ Class } & \multicolumn{3}{c}{ Kolmogorov-Smirnova } & \multirow{2}{*}{ Conclusion } \\
\cline { 2 - 4 } & Statistics & df & Sig. & H0 accepted \\
\hline Experiment & 0.200 & 15 & 0.133 & \\
\hline Control & 0.290 & 14 & 0.002 & H0 rejected \\
\hline
\end{tabular}

Based on Table 7 above, it can be seen that the N-Gain score for the concept understanding ability of the experimental class has a Sig value more than $\alpha=0.05$, which is 0.133 , while the control class is less than the value of 0.002 . This shows that the experimental class N-Gain data is normally distributed and the control class N-Gain data is not normally distributed. The test of two independent samples, the normality and homogeneity of the two variances must first be tested, with the criteria that if the two groups are normally distributed, it will proceed to the homogeneity test of the two variances and if it produces variance that is not homogeneous then it is continued with the t-test. If the two groups or one of the sample groups are not normally distributed, then continue with the Non-parametric statistical test in this case use the Mann Whitney Test. Based on the results of data processing in Table 7.

\section{b. N-Gain Average Difference Test Concept Understanding Ability}

Table 8. Test Results for Differences in Average N-Gain Concept Understanding Ability

\begin{tabular}{ccc}
\hline Mann Whitney & Sig (2-tailed) & Information \\
\hline 1,000 & 0.000 & H0 rejected \\
\hline
\end{tabular}

Table 8 above shows that the value of sig. (2-tailed) the N-Gain score is 0.000 less than 0.05 so that $\mathrm{HO}$ is rejected and $\mathrm{Ha}$ is accepted. Thus, it can be concluded that there is an increase in the N-Gain ability to understand concepts taught by the cooperative learning model of Think Talk Write (TTW) type with an average N-Gain ability to understand concepts taught by conventional learning. If viewed from the average value of $\mathrm{N}$-Gain in the experimental class and the control class, the experimental class N-Gain value is higher than the control class, so it can be concluded that the increase in the ability to understand concepts of the experimental class students is better than the control class.

The results of hypothesis testing indicate that there is a significant increase in the ability to understand concepts between students who get the Think Talk Write (TTW) type cooperative learning model and students who get a conventional approach. These findings 
strengthen the research of Yulianty (2019) which concluded that the ability to understand mathematical concepts among students taught with a realistic mathematics approach was better than conventional learning (Yulianti., 2019). Based on the results of the pretest and posttest, a normalized gain (N-Gain) was obtained the average normalized gain for the ability to understand concepts was obtained by sig. (2-tailed) N-Gain score 0.000 less than 0.05 . Thus, it can be concluded that there is a difference between the average N-Gain of the ability to understand concepts taught by the cooperative learning model of Think Talk Write (TTW) type and the average N-Gain of the ability to understand concepts taught by conventional learning. If viewed from the average value of $\mathrm{N}$-Gain in the experimental class and the control class, the experimental class N-Gain value is higher than the control class, so it can be concluded that the increase in the concept understanding ability of the experimental class students is better than the control class.

The results obtained from the study were significantly more able to improve students' conceptual understand skills with cooperative learning than conventional although the results obtained were not satisfactory. The results of this study strengthen the findings made by Indrayani, Mirna and Dwina (2018) showing that students' understand using the Think Talk Write model is better than understanding concepts using conventional learning. In other words, the Think Talk Write learning model has an effect on understanding the concept (Indrayani et al., 2018).

\section{Conclusions}

Based on the results of the pretest and post-test, a normalized gain (N-Gain) was obtained. (2-tailed) the N-Gain score of 0.000 is less than 0.05 , it can be concluded that there is an increase in the ability to understand concepts taught by the Think Talk Write (TTW) type cooperative learning model with an average increase in the ability to understand concepts taught by the model conventional learning.

\section{Acknowledgments}

I as a researcher would like to thank the LPPM of the Universitas Serambi Mekkah and RISTEKDIKTI who have given me the opportunity to participate in presenting my articles at this international seminar. I hope in the future that I can display better articles.

\section{References}

Suyanto, E. (2016). Pembelajaran Matematika Dengan Strategi TTW Berbasis Learning Journal untuk Meningkatkan Kemampuan Menulis Matematis. Kreano, J. Mat. Kreat., $7(1), 58-65$.

Novitasari, D. (2016). Pengaruh Penggunaan Multimedia Interaktif Terhadap Kemampuan Pemahaman Konsep Matematis Siswa. FIBONACCI J. Pendidik. Mat. dan Mat., 2(2).

Achmad, G. F., Eka, Z., and Henry, S. B., (2018). Realistic Mathematic Education Berbantu Alat Peraga Bongpas. J. Ilm. Pendidik. Mat., 1(1), 15-20, 2018.

Sri, T., and Asih, N. (2017). Analisis Kemampuan Pemahaman Konsep Matematika Ditinjau dari Rasa Ingin Tahu Siswa pada Model Concept Attainment. Unnes J. Math. Educ. Res., 6(2), 217-224.

Putri, S. E., Cahya, E., Asih, M., Matematika, D. P., and Indonesia, U. P. (2020). Upaya Meningkatkan Kemampuan Pemahaman Konsep Matematis. Math. Educ. Res., 1(1), 28 35 .

Indrayani, M., and Dwina, F. (2018). Model Pembelajaran Kooperatif Tipe Think Talk Write Untuk. J. Edukasi dan Penelit. Mat., 7(1), 48-53. 
Agus, C. I. W., Sastrawan, M., and Asnawati, R. (2017). Efektivitas Model Pembelajaran Think Talk Write ditinjau dari Pemahaman Konsep Matematis Siswa. J. FKIP Univ. Lampung, 87(1,2) pp. 149-200.

Kurniawati, T., Sutopo, and Ekana, C. H. (2018). Penerapan Model Pembelajaran Think Talk Write (TTW) dengan Strategi React Untuk Meningkatkan Aktivitas Belajar dan Pemahaman Konsep Matematika Siswa Kelas VIII E SMP Negeri 1 WEDI. J. Pendidik. Mat. dan Mat. Solusi, 2(4), 281-288.

Suryawati, I., Zubainur, C. M., and Munzir, S. (2019). Kemampuan Komunikasi Matematis Siswa Melalui Model Pembelajaran think Talk Write (Ttw). Concept Commun., 23, 301316.

Yulianty, N. (2019). Kemampuan Pemahaman Konsep Matematika Siswa Dengan Pendekatan Pembelajaran Matematika Realistik. Raflesia, 4(1), 60-65. 